\title{
Serological evidence of hepatitis E virus infection in an indigenous North American population
}

\author{
GY Minuk $M D^{1,2}$, A Sun BSc ${ }^{1}$, DF Sun $M D^{1}$, J Uhanova $M D^{1}$, LE Nicolle $M D^{1}$, B Larke $M D^{3}$, A Giulivi $M D^{4}$
}

GY Minuk, A Sun, DF Sun, et al. Serological evidence of hepatitis $\mathrm{E}$ virus infection in an indigenous North American population. Can J Gastroenterol 2007;21(7):439-442.

BACKGROUND: Hepatitis E virus (HEV) infections are thought to be uncommon in North America. Recently, HEV transmission has been reported following the consumption of deer meat. Because deer are closely related to caribou and caribou meat is a staple of the Canadian Inuit and the American Eskimo diet, the present study explored the seroprevalence of $\mathrm{HEV}$ infection in an isolated Canadian Inuit community.

METHODS: Stored sera were thawed and tested for immunoglobulin (Ig) $\mathrm{G}$ and IgM anti-HEV by ELISA, and tested for HEV-RNA by reverse transcriptase polymerase chain reaction.

RESULTS: The study consisted of 393 sera (representing approximately $50 \%$ of the community's inhabitants). Eleven samples (3\%) were $\mathrm{IgG}$ anti-HEV-positive. Their mean age was $29 \pm 8$ years and three were male. Two of $11(18 \%)$ were also IgM anti-HEV-positive. All IgG anti-HEV-positive individuals were HEV-RNA-negative. Liver biochemistry was normal in all. Seven of $11(64 \%)$ were also positive for anti-hepatitis A virus, five (46\%) were hepatitis B virus seropositive and none $(0 \%)$ were positive for anti-hepatitis $C$ virus. There were no associations between infections with HEV and other hepatropic viruses. Serological testing was negative for HEV infection in 25 caribou from an adjacent region.

CONCLUSION: The results of the present study showed that serological evidence of HEV infection was present in 3\% of the observed Canadian Inuit population; the presence of IgM anti-HEV suggested recent infection and HEV did not appear to coinfect with other common hepatotropic viruses. The source of HEV infection in the population remains unclear. These findings are interesting but preliminary. Additional data are required to determine whether HEV infections are responsible for otherwise unexplained acute hepatitis in the Canadian Inuit population and visitors returning from northern North American communities.

\section{Les signes sérologiques d'infection au virus de l'hépatite $E$ au sein d'une population indigène nord-américaine}

HISTORIQUE : On pense que les infections au virus de l'hépatite E (VHE) sont rares en Amérique du Nord. Les chevreuils sont des réservoir animaux connus du VHE et sont étroitement reliés aux caribous. La viande de caribou est un aliment de base du régime des Inuits du Canada et des Esquimaux américains. La présente étude portait sur la séroprévalence d'infection au VHE au sein d'une communauté inuite isolée afin de déterminer si la population présentait des signes de l'infection.

MÉTHODOLOGIE : Le sérum entreposé a été décongelé et on a évalué l'immunoglobuline (Ig) G et IgM par le test ELISA et le VHE-ARN par la réaction en chaîne de la polymérase de la transcriptase inverse.

RÉSULTATS : L'étude se composait de 393 sérums (représentant environ $50 \%$ des habitants de la collectivité), dont 11 échantillons (3\%) étaient positifs à l'IgG et au VHE. Ils avaient un âge moyen de $29 \pm 8$ ans et trois (30\%) étaient de sexe masculin. Deux des $11(18 \%)$ individus étaient également négatifs à l'IgM et au VHE. Tous avaient une biochimie hépatique normale. Sept des 11 (64 \%) individus étaient également positifs au virus anti-hépatitique $\mathrm{A}$, cinq $(46 \%)$ au virus de l'hépatite $\mathrm{B}$ et aucun $(0 \%)$ au virus anti-hépatitique C. Il n'y avait pas d'associations entre les infections au VHE et les autres virus hépatropiques. Les tests sérologiques étaient négatifs à l'infection au VHE chez 25 caribous d'une région avoisinante.

CONCLUSION : Les résultats de la présente étude révèlent qu'on constatait des signes sérologiques d'infection au VHE chez $3 \%$ des membres de la population inuite canadienne observée. La présence d'IgM antiVHE indiquait une infection récente, et le VHE ne semblait pas être coinfecté par d'autres virus hépatrotropiques courants. La source de l'infection au VHE au sein de la population n'est toujours pas claire. Ces observations sont intéressantes, mais préliminaires. Il faudra colliger des données supplémentaires pour déterminer si les infections au VHE sont responsables d'une hépatite aiguë inexpliquée au sein de la population inuite canadienne, de la population d'Esquimaux américains et chez les visiteurs revenant de communautés nord-américaines du Grand Nord.

Key Words: Acute hepatitis; Canada; Hepatitis E virus; Liver; Liver disease; Viral hepatitis

$\mathrm{T}$ he hepatitis $\mathrm{E}$ virus (HEV) is a nonenveloped, spherical RNA virus that was initially classified as a calicivirus but is now considered a member of the Hepeviridae family of RNA viruses (1). Clinical presentations of HEV infection in humans are similar to most other forms of acute viral hepatitis, with the exception that mortality rates can approach $20 \%$ in pregnant women $(2,3)$. Chronic infection with this virus does not occur (4).

The diagnosis of acute HEV infection is largely confined to serological testing and molecular genomic analysis by reverse transcriptase polymerase chain reaction (RT-PCR) $(5,6)$.

Thus, to diagnose acute HEV, either immunoglobulin (Ig) M anti-HEV or RT-PCR testing can be used $(7,8)$. For evidence of previous infection, IgG anti-HEV is considered to be highly sensitive and specific (greater than 95\%, respectively) $(9,10)$.

HEV is transmitted by the fecal-oral route (1). Typically, this involves ingesting water or food contaminated by infected feces (6). Recent studies (11-14) have reported that HEV can be detected in primates, swine and deer, and that humans can become infected by consuming the meat of these animals. Because North American caribou are closely related to deer, it is possible

${ }^{1}$ Department of Medicine; ${ }^{2}$ Department of Pharmacology and Therapeutics, University of Manitoba, Winnipeg, Manitoba; ${ }^{3}$ Yukon Health and

Social Services, Whitehorse, Yukon; ${ }^{4}$ Centre for Infectious Disease Prevention and Control, Public Health Agency of Canada, Ottawa, Ontario Correspondence: Dr Gerald Y Minuk, Section of Hepatology, University of Manitoba, John Buhler Research Centre, 803F - 715 McDermot Avenue,

Winnipeg, Manitoba R3E 3P4. Telephone 204-789-3204, fax 204-789-3971, e-mail gminuk@cc.umanitoba.ca

Received for publication September 8, 2006. Accepted October 22, 2006 


\section{TABLE 1}

Anti-hepatitis E virus (anti-HEV) seropositivity in an isolated Canadian Inuit population

\begin{tabular}{|c|c|c|c|c|c|c|c|c|}
\hline Patient & Age, years & Sex & IgG anti-HEV & IgM anti-HEV & HEV RNA & Anti-HAV & $\begin{array}{c}\text { HBV- } \\
\text { seropositive }\end{array}$ & Anti-HCV \\
\hline 2 & 8 & Male & + & - & - & + & - & - \\
\hline 4 & 15 & Female & + & - & - & - & + & - \\
\hline 5 & 16 & Female & + & - & - & + & + & - \\
\hline 8 & 43 & Female & + & - & - & + & + & - \\
\hline 9 & 67 & Female & + & + & - & + & + & - \\
\hline 10 & 87 & Female & + & + & - & + & + & - \\
\hline 11 & 9 & Unknown & + & - & - & - & - & - \\
\hline Anti-HEV+ $(n=11)$ & $29 \pm 8^{*}$ & $30 \%$ male & $100 \%$ & $18 \%$ & $0 \%$ & $64 \%$ & $46 \%$ & $0 \%$ \\
\hline
\end{tabular}

${ }^{*}$ Mean \pm SD. - Negative; + Positive; HAV Hepatitis A virus; HBV Hepatitis B virus-seropositive (either HBV surface antigen or antibody to HBV core or surface antigen-positive); HCV Hepatitis C virus; IgG/M Immunoglobulin G/M; NT Not tested

that caribou may also carry the HEV infection. This could represent a potential health risk to the Canadian Inuit because caribou meat is a staple of their diet. The purpose of the present study was to document the prevalence of serological markers for HEV infection in a remote, northern Canadian Inuit community.

\section{PATIENTS AND METHODS}

\section{Study population and serological testing}

The study community is an inland settlement south of the Arctic Circle and north of the Canadian treeline. The size of the community at the time the samples were collected (1980) was approximately 800 individuals (15).

Most families within the community derive their income from hunting, fishing or federal government assistance. Travel in and out of the community is largely by plane, and is limited to individuals visiting family members in adjacent communities and medical evacuations to the nearest medical centre in Churchill, Manitoba. Most, if not all, community inhabitants have not travelled outside Canada. Tourist activity is limited.

Caribou meat, fish and processed food from southern Canadian centres constitute the staple diet. Caribou meat is usually eaten raw when obtained by hunting 'on the land'. Caribou meat stored outside of dwellings within the community is either eaten raw, fried, or cooked in warm or hot water for $30 \mathrm{~min}$ to $45 \mathrm{~min}$.

Human serum samples from inhabitants of the community, which were collected in 1980 and kept frozen at $-80^{\circ} \mathrm{C}$, were thawed for testing (15). For each individual, their dwelling within the community was assigned a number and their status within the family unit (eg, father, mother, son, etc) was recorded. Caribou sera (kindly provided by Drs Rick Farnell, Philip Merchant and Dorothy Cooley, Yukon Department of Environment, Whitehorse, Yukon) were derived from the Porcupine and Chisana Woodland herds in regions adjacent to the study community. Serological testing was performed using commercially available kits from Genelabs Diagnostics (USA). ELISA was used to detect $\operatorname{IgG}$ and IgM anti-HEV following the manufacturer's instructions. Samples that were $\operatorname{IgG}$ anti-HEV-positive were retested in duplicate. If all three test results were positive, the sample was considered positive and was further tested (in duplicate) for IgM anti-HEV and HEV RNA. HEV RNA testing was performed by RT-PCR. Serum RNA was isolated using a High Pure Viral RNA Kit (Roche Diagnostics, Canada) and RT-PCR was performed as described by Mizuo et al (16). Positive controls were provided by Dr C Osiowy at the National Microbiology Laboratory in Winnipeg, Manitoba. Serological testing for hepatitis $A$ virus (HAV), hepatitis $B$ virus (HBV) and hepatitis $C$ virus (HCV) infections was performed as described previously $(15,17)$.

All individuals or their guardians provided informed consent in 1980 for future testing of newly discovered hepatotropic viruses and/or variants of established causes of viral hepatitis. The study protocol was approved by the University of Manitoba's Biomedical Research Ethics Board.

\section{Statistics}

Categorical variables were evaluated using $\chi^{2}$ analysis. The $\chi^{2}$ test of association (or $F$ test when warranted) was used to examine whether the presence of anti-HEV was associated with positive results of serological testing for HAV, HBV or HCV. Continuous variables were compared using Student's $t$ test. Statistical significance was achieved when $\mathrm{P}$ values fell below 5\% in all analyses. Statistical analyses were performed using NCSS and PASS statistical software (NCSS, USA).

\section{RESULTS}

The study sample consisted of 393 sera (representing approximately $50 \%$ of the community inhabitants), 11 (3\%) of whom were IgG anti-HEV-positive (Table 1). Their mean age was $29 \pm 8$ years and three of the $10(30 \%)$ in whom sex was known were male. Two of the 11 samples (18\%) were IgM anti-HEVpositive. Neither of these nor the remaining nine $\operatorname{IgG}$ antiHEV-positive samples were HEV-RNA-positive. All 11 anti-HEV-positive individuals had normal liver enzyme tests (serum aminotransferases, alkaline phosphatase and gamma glutamyl transpeptidase levels) and were rheumatoid factornegative. Seven (64\%) were anti-HAV-positive, five (46\%) were HBV seropositive (either HBV surface antigen, or antibody to HBV surface or core antigen-positive) and none (0\%) were anti-HCV-positive. There were no associations between the presence of anti-HEV and positive serology for HAV, HBV or HCV. When analyzed with respect to family dwellings, none 
of the 11 anti-HEV-positive individuals resided in the same dwelling, nor were they first-degree relatives to each other.

The age and sex distributions of the remaining 382 antiHEV-negative individuals are also provided in Table 1 . Their mean age was $22 \pm 1$ years and 194 (51\%) were male. Two hundred seven (68\%) had been previously documented to be antiHAV-positive, 86 (22\%) HBV seropositive and four (1.0\%) anti-HCV-positive $(15,17)$.

$\operatorname{IgG}$ and IgM anti-HEV testing in all 25 caribou sera was negative.

\section{DISCUSSION}

To date, essentially all reported cases of HEV in Canada have been described in travellers returning from tropical and/or developing nations $(18,19)$. The prevalence of $\mathrm{HEV}$ in a community-based North American population or, indeed, any community-based population throughout the world has yet to be reported. Although the results of the present study are limited to one community of a selected Canadian population, they do suggest that HEV infections unrelated to travel or working with pigs are occurring in North America and specifically within this northern indigenous population.

The 3\% prevalence rate described in the present study should only be considered to be an estimate of the true prevalence of HEV in this region. The half-life of IgG anti-HEV is relatively short and may become negative within one year of infection $(20,21)$. Thus, other community inhabitants may have been infected with HEV in the more remote past, but were seronegative at the time blood samples were obtained. False-positive results must also be considered. Although all positive specimens were tested in triplicate and were negative for rheumatoid factor, the presence of a not yet recognized cross-reacting antibody cannot be excluded.

Two of the 11 anti-HEV-positive samples also tested positive for IgM anti-HEV, consistent with recent HEV infections. However, the normal liver enzymes and negative HEV-RNA testing in these samples would be unusual for acute HEV. Whether these specimens are false-positive for IgM anti-HEV or reflect the known decline in serum aminotransferases and viral RNA stability with storage of sera over prolonged periods of time remains to be determined $(22,23)$.

\section{REFERENCES}

1. Purcell RH, Emerson SU. Hepatitis E virus. In: Knipe D, Howley P, Griffin D, Lamb R, Martin M, Straus S, eds. Field's Virology, 4th edn. Philadelphia: Lippincott Williams \& Wilkins. (In press)

2. Fix AD, Abdel-Hamid M, Purcell RH, et al. Prevalence of antibodies to hepatitis $\mathrm{E}$ in two rural Egyptian communities. Am J Trop Med Hyg 2000;62:519-23.

3. Kumar A, Beniwal M, Kar P, Sharma JB, Murthy NS. Hepatitis E in pregnancy. Int J Gynaecol Obstet 2004;85:240-4.

4. Poddar U, Thapa BR, Prasad A, Sharma AK, Singh K. Natural history and risk factors in fulminant hepatic failure. Arch Dis Child 2002;87:54-6.

5. Mansuy JM, Peron JM, Abravanel F, et al. Hepatitis E in the south west of France in individuals who have never visited an endemic area. J Med Virol 2004; 74:419-24.

6. Richman DD, Whitley RJ, Hayden FG. Clinical Virology, 2nd edn. Washington, DC: ASM Press, 2002:1061-71.

7. Mitsui T, Tsukamoto Y, Suzuki S, et al. Serological and molecular studies on subclinical hepatitis $\mathrm{E}$ virus infection using periodic serum samples obtained from healthy individuals. J Med Virol 2005;76:526-33.

8. Reyes GR, Huang CC, Yarbough PO, Tam AW. Hepatitis E virus. Comparison of 'New and Old World' isolates. J Hepatol 1991;13:S155-61.
That anti-HEV positivity was not associated with serological evidence of infection with other hepatotropic viruses, and HAV in particular, suggests that in this community, the two viruses may be transmitted by different routes. In the case of $\mathrm{HEV}$, given the reported transmission of HEV from deer to humans, and similarities between deer and caribou, it is proposed that consumption of uncooked or insufficiently cooked caribou meat may be responsible $(13,14)$. In the case of $\mathrm{HAV}$, contaminated drinking water within the community has been implicated most often (24). Similarly, a lack of association with serological evidence of HBV argues against maternalinfant HEV transmission, the most common mode of HBV infection in the community (15). There were too few antiHCV-positive cases to explore an association with this virus and thereby implicate parenteral routes of HEV infection in this community.

The negative HEV results in caribou sera argue against the possibility that caribou meat is responsible for introducing HEV into the community. However, it should be noted that the caribou tested were from Woodland rather than Barrenland herds, the latter being consumed by this particular Inuit population. Moreover, the prevalence of HEV infection in caribou may be low, rendering 25 serum samples insufficient for the present study. Finally, the serological assays used for caribou testing incorporated goat anti-human Ig which may not have captured caribou Ig. Thus, further testing of caribou and other components of the Inuit diet are warranted.

\section{CONCLUSION}

Approximately 3\% of this Canadian Inuit population have serological evidence of HEV infection. These results support the need for further studies to determine whether HEV is the cause of unexplained acute hepatitis in individuals residing in or visiting the northern regions of North America.

ACKNOWLEDGEMENTS: The present study was supported by a grant from the Bloodborne Pathogens Section of the Public Health Agency of Canada (Ottawa, Ontario). The authors would like to thank Ms T Chicheluk for her prompt and accurate typing of the manuscript. Dr A Sun is the recipient of a Canadian Liver Foundation Summer Student Award.

9. Mast EE, Alter MJ, Holland PV, Purcell RH. Evaluation of assays for antibody to hepatitis $\mathrm{E}$ virus by a serum panel. Hepatitis $\mathrm{E}$ Virus Antibody Serum Panel Evaluation Group. Hepatology 1998;27:857-61.

10. Tsarev SA, Tsareva TS, Emerson SU, et al. ELISA for antibody to hepatitis $\mathrm{E}$ virus (HEV) based on complete open-reading frame-2 protein expressed in insect cells: Identification of HEV infection in primates. J Infect Dis 1993;168:369-78.

11. van der Poel WH, Verschoor F, van der Heide R, et al.

Hepatitis $\mathrm{E}$ virus sequences in swine related to sequences in human, The Netherlands. Emerg Infect Dis 2001;7:970-6.

12. Takahashi K, Kitajima N, Abe N, Mishiro S. Complete or near-complete nucleotide sequences of hepatitis $\mathrm{E}$ virus genome recovered from a wild boar, a deer, and four patients who ate the deer. Virology 2004;330:501-5.

13. Tei S, Kitajima N, Ohara S, et al. Consumption of uncooked deer meat as a risk factor for hepatitis $\mathrm{E}$ virus infection: An age-and sex-matched case-control study. J Med Virol 2004;74:67-70.

14. Tei S, Kitajima N, Takahashi K, Mishiro S. Zoonotic transmission of hepatitis $\mathrm{E}$ virus from deer to human beings. Lancet 2003;362:371-3.

15. Minuk GY, Nicolle LE, Postl B, Waggoner JG, Hoofnagle JH. Hepatitis virus infection in an isolated Canadian Inuit (Eskimo) population. J Med Virol 1982;10:255-64. 
16. Mizuo H, Suzuki K, Takikawa Y, et al. Polyphyletic strains of hepatitis $\mathrm{E}$ virus are responsible for sporadic cases of acute hepatitis in Japan. J Clin Microbiol 2002;40:3209-18.

17. Minuk GY, Nicolle LE, Gauthier T, Brunka J. The prevalence of antibody to hepatitis $C$ virus in an isolated Canadian Inuit settlement. Can J Infect Dis 1991;2:71-3.

18. Chaudhary RK, Morbey M, Yarbough PO. Detection of hepatitis E virus antibody in Canada. Can J Infect Dis 1995;6:264-5.

19. Statistics and Risk Assessment Section, Health Care Acquired Infections Division, Centre for Infectious Disease Prevention and Control. Blood-borne pathogens routine surveillance system report. Can Commun Dis Rep 2002;28(Suppl 2):1-59.

20. Liao S, Yang Z, Jiang Y, Zhan M. [Dynamic changes of serum antibody titer and liver ultrastructural pathology in acute sporadic hepatitis E virus infected patients.] Zhonghua Shi Yan He Lin Chuang Bing Du Xue Za Zhi 1997;11:244-6.

21. Favorov MO, Khudyakov YE, Mast EE, et al. IgM and IgG antibodies to hepatitis $\mathrm{E}$ virus (HEV) detected by an enzyme immunoassay based on an HEV-specific artificial recombinant mosaic protein. J Med Virol 1996;50:50-8.

22. Cuccherini B, Nussbaum SJ, Seeff LB, Lukacs, Zimmerman HJ. Stability of aspartate aminotransferase and alanine aminotransferase activities. J Lab Clin Med 1983;102:370-6.

23. Vaughan H, Chalker VJ, Mee Z, Rossouw A, James V. Stability of lyophilised specimens for the molecular detection of viral DNA/RNA. J Clin Virol 2006;35:135-40.

24. Minuk GY, Waggoner JG, Jernigan R, Nicolle LE, Postl B, Hoofnagle JH. Prevalence of antibody to hepatitis A virus in a Canadian Inuit community. Can Med Assoc J 1982;127:850-2. 


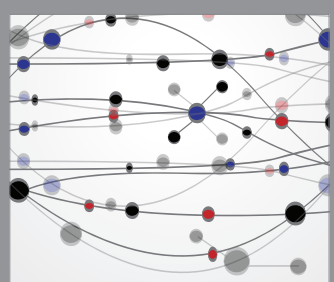

The Scientific World Journal
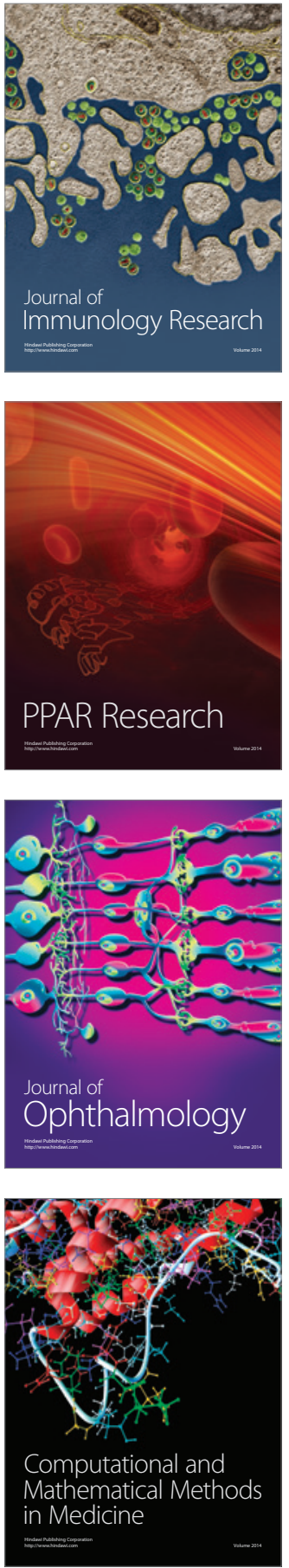

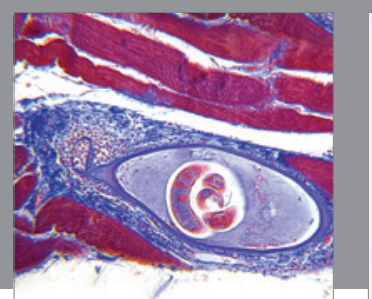

Gastroenterology Research and Practice

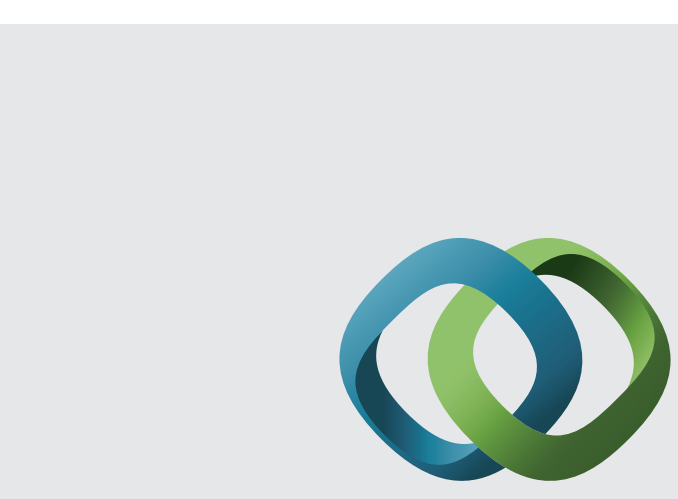

\section{Hindawi}

Submit your manuscripts at

http://www.hindawi.com
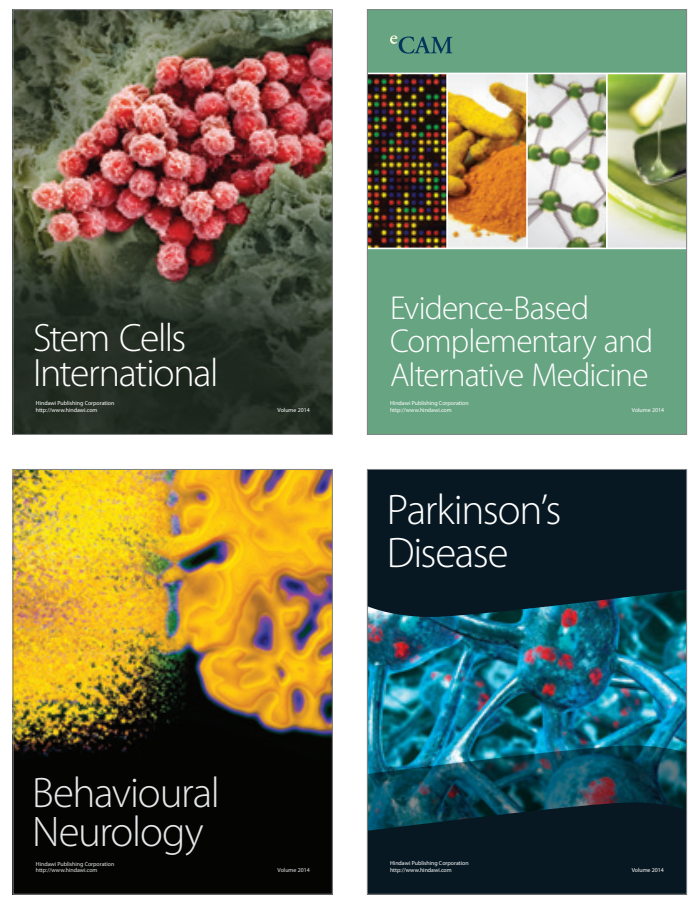
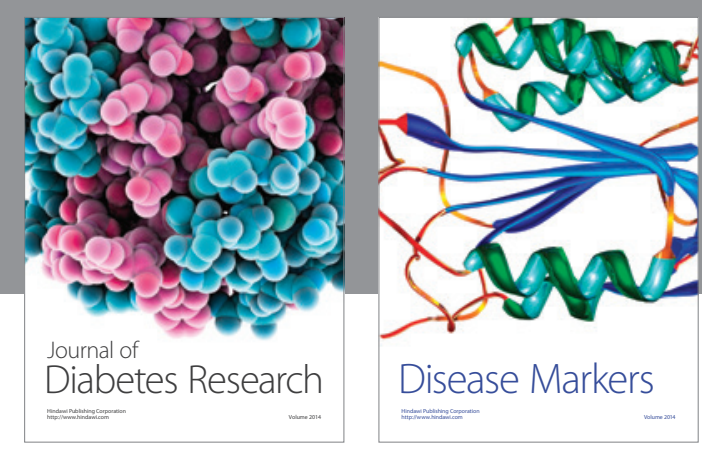

Disease Markers
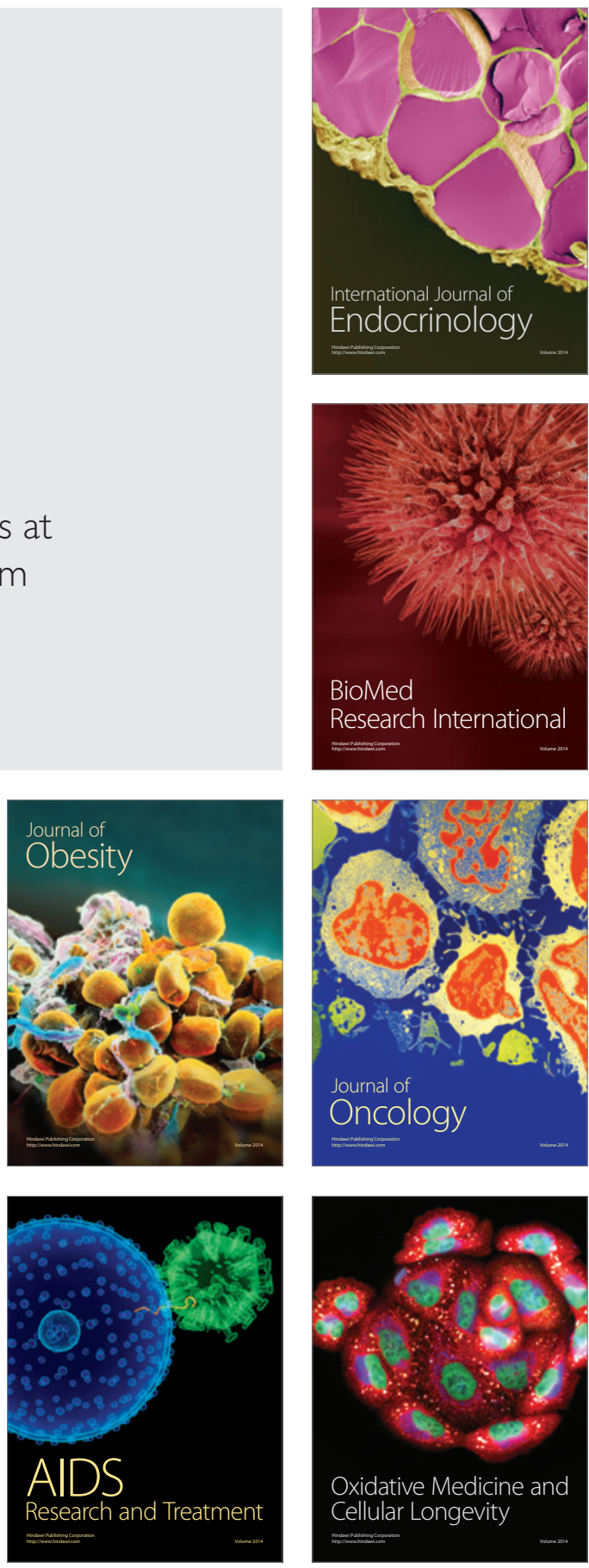